\title{
Regional Chemotherapy
}

National Cancer Institute

\section{Source}

National Cancer Institute. Regional Chemotherapy. NCI Thesaurus. Code C15912.

A form of chemotherapy in which the drug(s) are placed into a specific location, including a body cavity or individual organ, for the purpose of killing cancer cells whilst minimizing systemic toxicity. 